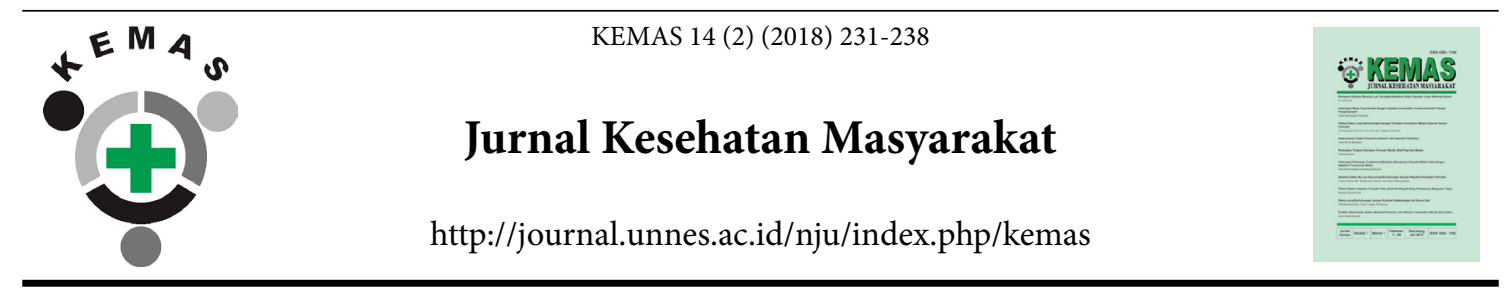

\title{
Counseling and Individual Factors on Postpartum Mother to Use Contraceptive Method
}

\author{
Theresia Mindarsih ${ }^{1}$, Ina Debora Ratu Ludji ${ }^{2}$, Marthen R. Pelokilla ${ }^{1}$ \\ ${ }^{1}$ Universitas Nusa Cendana, Indonesia \\ ${ }^{2}$ Politeknik Kementrian Kesehatan Kupang, Indonesia
}

\begin{tabular}{l} 
Article Info \\
\hline Article History: \\
Submitted June 2017 \\
Accepted June 2018 \\
Published November 2018 \\
\hline Keywords: \\
Counseling, \\
postpartum, \\
contraception usage \\
\hline DOI \\
https://doi.org/10.15294/ \\
kemas.v14i2.10149
\end{tabular}

\begin{abstract}
During postpartum period, mother needs counseling on the usage of contraception tools. Contraception is needed before menstruation returns to prevent pregnancy. The purpose of this research was to investigate the influence postpartum counseling and mother's individual factors on contraception usage in Kupang City. This was a quasiexperimental study. 64 respondents were selected through purposive sampling and divided into 2 groups, 32 people were given counseling and 32 were not. Data was collected using questionnaires. Data analysis was bivariate and multivariate. The result showed 22 respondents $(68.75 \%)$ received counseling about postpartum contraception and $8(25 \%)$ did not. The result of chi square test showed significant value of $\rho=0.000$, indicating that postpartum maternal counseling influenced contraception usage. Therefore, postpartum maternal counseling affected contraception method usage by mothers in Kupang City.
\end{abstract}

\section{Introduction}

High population growth is a problem for a country. Population control towards a desired population growth rate could be done by the government through policies and activities related to population control. According to 2017 Government Work Plan draft, one of the national priority in health development is improving family planning and reproductive health services (BKKBN, 2016).

The Family Planning Program (KB) has an important contribution in regulating birth rate and improve population's quality. The role of health workers in KB-related community service is providing family planning counseling for women and couples of childbearing age. Counseling about family planning or contraceptive methods should be given during antenatal and postpartum care (Affandi, 2011).

The puerpurium period begins one hour after placental birth until six weeks (42 days). Postpartum services must be conducted during puerperium period to meet the needs of both mother and her baby, which includes prevention, early detection and treatment of complications $\&$ diseases, provision of breastfeeding services, methods to space pregnancies, immunizations and nutrition for mothers. During postpartum period, mothers need counseling on the use of contraceptive methods.

Married couples should wait at least 2 years before another pregnancy. Every couple must be able to determine and plan their own family size. Health workers can help family planning by teaching about unwanted pregnancies prevention through contraceptive

\footnotetext{
$\triangle$ Correspondence Address:

Jl. Adisucipto - Kupang 85001.

Email : tehamindarsih@yahoo.com 
methods. The use of contraceptive methods is needed before menstruation resumes to prevent pregnancy. In the Continuum of care approach, counseling about early breastfeeding initiation and postpartum family planning is needed for mothers in parturition, postpartum and neonatal periods (BKKBN, 2016). One of the objectives of Family Planning service policy is the provision of quality counseling services (Affandi, 2011).

Given the importance of counseling for postpartum mothers to improve maternal and child health, the authors were interested in conducting a study on the effect of postpartum maternal counseling on contraceptive methods usage in Kupang City in 2017.

Method

This is a quasi-experimental study with non-randomized pretest-posttest group design. The population in this study were all postpartum mothers in Kupang city. Sample size was calculated using the Lemenshow formula, and a sample size of 64 people was obtained.

The study was conducted in 11 health centers throughout Kupang City. Sampling from the existing population was done purposively (purposive sampling), whereas research subject was determined by certain criteria that were determined based on research objectives. The independent variable in this study was the influence of counseling. The dependent variable in this study was the use of contraceptive methods in postpartum mothers. The research instrument used was questionnaire. The type of data analysis used was bivariate analysis, and multivariate.

Bivariate analysis was performed to see the effect of independent variables on the dependent variable and how much influence it would have if it was associated with ChiSquare statistical test and multivariate analysis through logistic regression test, so that the most dominant variable which influence contraceptive methods usage could be determined.

\section{Results and Discussion}

Bivariate analysis in this study used the chi-square test to see the effect of independent variables on dependent variables.
Bivariate analysis on the influence of postpartum counseling on contraceptive usage in counseling group and non-counseling group. Table 1. Effects of Counseling in Contraception Methods Usage

\begin{tabular}{llll}
\hline No & Variable & Result & Significance \\
\hline 1 & Age & 0,503 & Not Significant \\
2 & Education & 0,331 & Not Significant \\
3 & Parity status & 0,192 & Not Significant \\
4 & Social-economy & 0,060 & Not Significant \\
5 & Knowledge & 0,005 & Significant \\
\hline
\end{tabular}

From Table 1, we can conclude that age, education, parity and socio-economics had no significant effect on contraceptive methods usage, while knowledge had a significant effect on contraceptive methods usage.

The final result of the fifth multivariate analysis for independent variable on the dependent variable found two most dominant variables, namely counseling in postpartum mothers with $\mathrm{p}$ value $0.005 \quad(<0.05)$ and knowledge with $p$ value 0.30 .

Out of the 64 respondents, most were aged 20 to 35 years-old (26 in the treatment group and 32 in the control group). The result of chi-square test showed a probability value ( $p$ value) of 0.503 ( $p>0.05$ ), meaning that age had no significant influence on contraceptive methods usage.

Based on the 2012 SDKI data, younger (15-19 years) and older (45-49 years) women were less likely to use contraception compared to women in the middle of childbearing age (2044 years). The use of contraception in married women of all age groups was dominated by modern contraceptive methods (SDKI, 2012). Women under the age of 20 were most likely to have unmet needs for family planning. This was particularly important because pregnancy and childbirth is the main cause of death among women between 15 and 19 years-old (Pasha $e t$ al., 2015). Pregnancy in a very young age still occurs among adolescents (15-19), 1.97\% in rural areas, which is $2.71 \%$ higher than urban areas $(1.28 \%)$. In EFA, pregnancy prevention must be continuously promoted by forming an independently conscious society by using contraception (Chasanah, 2016). Contraceptive is important for couples of childbearing 
age, given the high risk of pregnancy. Age categorization in this study was based on the selection of rational contraceptives and healthy reproductive age, because the optimal age for pregnancy is 20-35 years. In addition, this age classification was based on the risk for pregnancy and childbirth complications.

This study is different from previous studies because most respondents were of healthy reproduction age (20-35 years). Most respondents said that they still want to give birth again even though there was a desire to postpone pregnancy. On average, they still want more children and some even want 4 children. Respondents in this study were aged 20-35 years old, so they did not feel any need for a contraception method. At the age of less than 20 years, pregnant women had a higher pregnancy risk due to the immaturity of their reproductive organs, hence babies born to mothers less than 20 years old could be afflicted with physical or mental disabilities. For pregnant women older than 35 years old, pregnancy risk is increased because the muscles elasticity has decreased, body and health condition has also started to decline which could affect maternal health and hence maternal death. Based on the pregnancy risk, age of $<20$ years could be seen as pregnancy delaying period, age 20-35 years-old of birth spacing period while age $>35$ years-old is birth limiting period. $\mathrm{KB}$ is a program that helps couples to postpone the birth of their first child, spacing pregnancy or limiting the number of desired children according to medical security and the possibility of the return of the fertility phase (fecundity).

The average respondent in this study had a moderate level of education (junior and senior high school graduates), 25 respondents among those who don't use contraception and 21 respondents among those who used contraception. The results of the chi-square test showed a probability value ( $\mathrm{p}$ value) of 0.331 ( $p>0.05$ ), meaning that education level had no significant effect on contraceptive usage.

Republic of Indonesia Law Number 20 Year 2003 concerning National Education System stated that formal education is a structured and tiered educational path consisting of basic education, secondary education, and higher education. The results of studies in several developing countries, including Indonesia, had proven that almost $35 \%$ of births or at least 200 million births were classified as Unmet KB Need or the occurrence of births due to absence of contraception. The high number of Unmet KB Need was mostly experienced by very poor families, had low education level, lived in poor urban areas and experienced by women under 19 yearsold (Helmizar, 2014). Most illiterate women (50.8\%), 30.8\% want to receive family planning method, felt the same need (36.4\%) as was observed among mothers of primary school graduates (Ansari et al., 2015).

This study is different from previous studies. Respondents' average level of education was moderate. They obtained information about family planning methods from neighbors, close relatives and radio, which may not be complete information. The education level of postpartum mothers can influence their attitude towards family planning choices, for example low education and illiteracy might make some unaware of family planning method's benefits. Promotion of family planning methods is still needed for postpartum mothers even though their average education level was junior and senior high school graduates. Complete and accurate information is very important in determining the contraceptive method of choice. The information they received may be false or incomplete due to various obstacles, hence family planning counseling needs to be more complete, clear and accurate so that they can choose postpartum contraception actively and independently. Information on contraceptive methods should be given immediately after parturition, which includes how to use, advantages, disadvantages, and side effects.

In this study, the majority of respondents were included in medium parity counseling group who used contraception (15 respondents) and low parity control group who did not use contraception (15 respondents). The results of chi-square test show the probability value ( $p$ value) of 0.192 ( $p>0.05)$, hence parity had no significant effect on contraceptive usage.

Parity is the number of pregnancies that produce a fetus capable of living outside the uterus. Parity at interval of less than 2 years 
and number of pregnancies above 4 times are problems that affects reproduction. The 2012 IDHS data showed that contraceptive use has increased in accordance to the number of living children. The use of contraceptive methods ranged from $7 \%$ among women who did not have children to $70 \%$ among women with three or four living children, then dropped to $52 \%$ for women with five living children or more. The results showed that the number of children was associated to interest in using KB. The higher the number of children, the higher the interest in participating in family planning programs. Hence, it can be concluded that family planning interest is caused by too many children instead of birth spacing or family quality. Likewise, family planning participation is also associated to the number of children. The higher number of children strengthened the decision to participate in family planning program (Sudarti and Prasetyaningtyas, 2011). Contraceptive use seems to increase with the age of the youngest child, $27 \%$ of women with their youngest child 1 year and above are using contraception, compared to $22 \%$ of women with their youngest child under 1 year of age. Contraceptive use increased with the number of living children, $28 \%$ of women with three or more children are using contraceptive methods, compared with $15 \%$ of women with only one child. Compared to women who wanted additional children or were hesitant, contraceptive use was almost twice as high among women who did not want additional children (19\% vs 36\%) (Agha and Williams, 2016) the use of maternal health services has increased dramatically in Pakistan, with nearly $80 \%$ of Pakistani women making an antenatal care (ANC).

This study is different than other studies. Our study respondents had 2 children on average, with 2 years space between parturition. Most respondents have private jobs with no restrictions on the number of children even though their income is relatively low. Low parity level means having a low birth rate, so the number of children is limited. High parity negatively affect postpartum maternal health. Mothers with high parity have increased risk in both pregnancy and labor.

In this study, most respondents were classified into low socio-economic status who used contraception (27 respondents) and low socio-economic status who did not use contraception (25 respondents). Chi-square test showed a probability value ( $\mathrm{p}$ value) of 0.060 ( $p>0.05$ ), hence socio-economic status had no significant influence on contraceptive usage.

Contraceptive usage is affected by family's economic status. 2012 SDKI collected data on house characteristic and ownership of durable goods, which is used as the basis for calculating household wealth index. Based on wealth index by 2012 SDKI, contraception usage was higher among middle to high wealth index. According to Minister of Manpower and Transmigration Act No. 226 of 2000, there are 2 levels of wages: Level I of Regional Minimum Wage (UMR) which is Provincial Minimum Wages (UMP); and the level II UMR which is the Regency / City Minimum Wage (UMK). Family economic status is measured based on the ability to support all family members as measured by average family expenditure in one month. Economic status highly affects contraceptive usage, therefore not all families can be advised to use contraception. Family socio-economic status had no significant effect on the acceptance of the family planning in Southwest Nigeria. It was observed that the calculated value was 8.53 , while the critical value was 16.92 . The calculated value was less than the critical value at 0.05 alpha level of significance (Lanre, 2011).

This study was in line to previous study in which the average respondents had low socio-economic condition, showed by monthly income of $\mathrm{Rp} 1,500,000.00$ or less. Theoretically, the higher the income, the higher the contraception usage. Middle to high socio-economic class has easier access to information through television, radio, newspaper, or they could directly come to hospitals or other health services in order to obtain contraception-related information from healthcare providers. Family in low socio-economic condition prefer to look after their economy rather than contraception method. Primary household necessities will be their first 
priority, especially with the presence of a new baby, resulting in underestimation of contraception benefits.

Current study results showed that out of 64 respondents, $22(68.8 \%)$ postpartum women who were given counselling and 8 (25\%) postpartum mother who were not given any counselling accepted one contraception method. Thus, counselling had significant influence on postpartum women to use contraception $(\rho=0,000 ;$ OR $=5.116)$. The Odd Ratio means that contraception usage was 5.116 times greater for a postpartum women who were given a counselling compared to those who did not.

Counselling is part of Education and Information Communication (KIE). In postpartum peiod, most women wish to delay or prevent subsequent pregnancies for at least 2 years or they no longer want additional children. A study in Karang Klesem Village, South Purwokerto District, Banyumas Regency concluded that all couples in childbearing age who accepted contraception had received counselling, while most couples who did not use any contraception did not receive any counselling $54(76.1 \%)$. There were 17 respondents (23.9\%) who have been given counselling yet did not accept any contraception. Analysis showed a significant relationship between counselling and decision to use contraception $\rho=0.00$ (Sari et al, 2010). Family planning program should establish a good coordination with maternal and child program focusing on childbirth spacing or pregnancy prevention and ensure easy access for pregnant women during their ANC and PNC period to get be introduced to family planning methods (Mehata et al., 2014) little is known about the use of family planning and the determinants in Nepal during this period. This study explored pregnancy spacing, unmet need, family planning use, and fertility behaviour among postpartum women in Nepal using child level data from the Nepal Demographic and Health Surveys 2011. More than one-quarter of women who gave birth in the last five years became pregnant within 24 months of giving birth and 52\% had an unmet need for family planning within 24 months postpartum. Significantly higher rates of unmet need were found among rural and hill residents, the poorest quintile, and Muslims. Despite wanting to space or limit pregnancies, nonuse of modern family planning methods by women and returned fertility increased the risk of unintended pregnancy. High unmet need for family planning in Nepal, especially in high risk groups, indicates the need for more equitable and higher quality postpartum family planning services, including availability of range of methods and counselling which will help to further reduce maternal, perinatal, and neonatal morbidity and mortality in Nepal (Mehata et al., 2014). Other study stated that most woman $(68,4 \%)$ wanted to cease giving birth while $31.6 \%$ of them planned to delay having child (Ceylan et al., 2009). Despite family planning promotion campaign, active role of postpartum women in accepting contraception should be supported by healthcare provider, field officers, and printed/electronic media. The achievement of National Family Planning Program target in DKI Jakarta was strongly influenced by the quality of interaction between program managers and implementers at the District and Sub-District level with a $\mathrm{R}$ square value of 0.493 or 49.3 percent, supported by the role of Family Planning Managers and availability of family planning services (Simanjuntak et al, 2014). Implementation of Counselling and Choosing (CC) program in several national health centers along with community-based interventions, can play a key role in achieving Jordan goal of reducing the total fertility rate to 2.1 by 2030 (Kamhawia et al., 2013). The percentage of family planning participation in the counseling group was significantly higher than in the control group, which was $92.6 \%$ and $37.0 \%$ respectively ( $<<0.001$ ). This showed that counseling at the latent phase had a significant influence on postpartum family planning participation. The results of the RR calculation showed that subjects who received family planning counseling at the latent phase of labor were 2.5 times more likely to accept postpartum contraception compared to subjects who did not (Abbas et al, 2017). Substantial amount of mothers experienced difficulties during labor or immediately during the postpartum period because of the pressure, pain and stress of childbirth. Therefore, counselling during prenatal, labor, 
and postpartum period was required in order to increase mothers' knowledge on postpartum contraception. Family planning counselling should be given from pregnancy period and began with providing information about various contraception methods for postpartum women. The successful counselling was influenced by healthcare provider in a healthcare center. This is in accordance to the study which stated that less than $50 \%$ health centers were capable of giving contraception counselling, especially in the rural area, where most the healthcare services did not have counselling skills (Saka et al, 2012).

Counseling is a process of exchanging information and positive interactions between clients and officers (counselors) in order to help clients to make the right decisions suitable with their own conditions. We considered the importance of counseling to help mother choose and decide which type of contraception is suitable to their needs, since this could satisfy the patients and accept side effects that may occur during the contraception usage. Postpartum counselling is an activity between health workers and postpartum mothers in providing information about various types of safe contraceptive methods for postpartum mothers. The application of postpartum family planning is very important because the return of fertility to a mother after childbirth is unpredictable and can occur before the onset of the menstrual cycle, including in breastfeeding women. Contraception usage during postpartum period is very important for maternal and child health. Family planning plays important role in preventing unwanted pregnancy and reduce maternal and child mortality. Counselling is highly needed to increase postpartum mother's participation in contraceptive usage. In current research, there were several women who were given counselling but did not accept contraception due to several factors such as husband working outside of Kupang, busy work in the rice fields, worried about contraceptive side effects, and several other reasons because they no longer want to use any contraception. Besides, there were several postpartum mothers who was given counselling but had not become a contraceptive acceptor with several reasons including husband is busy while working in ricefields, mother will work outside Kupang after labor, busy taking care of children, and suggestions from relatives that they should wait for 2-3 months after labor to use contraception. In this research there were also several respondents who did not use any contraceptive methods and were not given any counselling. The absence of counselling can lead to a lack understanding of postpartum contraceptive methods which ultimately cause them to not choose any contraceptive method. Moreover, there were respondents who already had 4 children but delayed using contraception for 1 year. Furthermore, there were respondents who already had 3 children but prefer simple contraceptive method, i.e calendar method, because their husband disallow the usage of long-term contraception. Whereas respondents who used contraception but did not get counselling prefer to use injection contraceptive methods that can be served in auxiliary healthcare centers close to their house. Injection contraceptive method is the most preferred method by postpartum mothers. They usually follow the advices of relatives or close neighbors in choosing contraceptive methods. Postpartum mothers who did not get counselling and accompanied by a lack understanding of postpartum contraceptive methods lead to reduced contraceptive usage.

The results of this study showed higher mean value in the treatment group. The average value of knowledge of postpartum mothers in treatment group about contraceptive method in mean difference test was 65.09. Noncounselling group had average value of 56.68 . Other study in class XI of vocational high school (SMK) using Mann Whitney test asserted that was a significant posttest-pretst increase in adolescents' reproductive health knowledge in treatment group compared to control group $\mathrm{p}=0.001 \quad(\mathrm{p}=<0.05)$ (Rizki, 2012). In addition, hormonal contraception counseling had an effect on knowledge of post-partum family planning acceptors in the working area of the Lismarini Independent Practice Midwife, Palembang $(p-=0,005)$ (Amalia et al, 2016).

This research is suitable with the theoretical concept. It was known that a treatment (counseling about contraceptive methods) provides contact between postpatum 
mothers and health workers. Mothers should seek complete, accurate and correct information regarding contraceptive methods which could be obtained at healthcare facilities. Mothers should consider the effectiveness and efficiency of a contraceptive method. Currently, the types of modern contraceptive methods available are: hormonal contraception (pills, injections and implants), IUD, permanent contraception (vasectomy and tubectomy). The higher the knowledge of postpartum mothers, the greater is the likelihood of using the contraceptive method in postpartum mother

\section{Conclusion}

We conclude that the age, parity, education and socio-economy did not significantly influence contraceptive usage among postpartum mothers. Counselling in postpartum mothers had a significant effect in contraceptive method usage in the counseling and non-counseling groups $(\mathrm{p}=$ 0,000 ). There was a difference in mean and an increase in postpartum maternal knowledge on contraception before and after counseling.

Knowledge of postpartum mothers about contraceptive methods is highly important in order to decide a safe contraception method. A proper approach can change their knowledge and the choice of contraception, which through a personal approach will provide more effective results to increase knowledge as it can generate independent desire to use contraception.

Policy holders are expected to provide information and increase the motivation of health workers to conduct family planning counseling, as well as maintain the implementation of postpartum maternal counseling as an effort to improve family planning services. Managers of maternal and child health programs are recommended to improve the quality of postpartum maternal services by providing complete and simple counseling material regarding postpartum maternal contraceptive methods. Health workers are expected to provide postpartum maternal counseling according to standards, including side effects, mechanism of action, benefits, and detriments that is safe for postpartum mothers in order to foster their awareness to choose and use one of the contraceptive methods.

\section{References}

Abbas, M., Hadijono, S., Emilia, O., \& Hartono, E., 2017. Pengaruh Konseling Saat Persalinan terhadap Kepesertaan Keluarga Berencana Pasca Salin di Kabupaten Kolaka. Jurnal Kesehatan Reproduksi, 4(2), pp.127-134.

Affandi, B., 2011. Buku Panduan Praktis Pelayanan Kontrasepsi. Jakarta: Bina Pustaka.

Agha, S., \& Williams, E., 2016. Does the Antenatal Care Visit Represent A Missed Opportunity for Increasing Contraceptive Use in Pakistan? An Analysis of Household Survey Data from Sindh Province. Health Policy and Planning, 31(3), pp.325-331.

Amalia, S., Afriyani, R., \& Sari, Y.P., 2016. Pengaruh Konseling Kontrasepsi Hormonal terhadap Tigkat Pengetahuan Akseptor Keluarga Berencana Pasca Persalinan di Wilayah Kerja Bidan Praktik Mandiri Lismarini Palembang. Jurnal Kesehatan, 7(2).

Ansari, M.A., Mehnaz, S., Abedi, A.J., Shah, M. S., \& Khan, Z., 2015. Exploring Demographic Factors Influencing Acceptance of Family Planning Methods in Aligarh. BioMedical and Clinical Research, 1(2).

BKKBN., 2016. Kebijakan Program Kependudukan Keluarga Berencana dan Pembangunan Keluarga dalam Mendukung Keluarga Sehat. Jakarta.

Ceylan, A., Ertem, M., Saka, G., \& Akdeniz, N., 2009. Post Abortion Family Planning Counseling As A Tool to Increase Contraception Use. BMC Public Health, 9.

Chasanah, S.U., 2016. Peran Petugas Kesehatan Masyarakat dalam Upaya Penurunan Angka Kematian Ibu Pasca MDGs 2015. Jurnal Kesehatan Masyarakat, 9.

Helmizar, H., 2014. Evaluasi Kebijakan Jaminan Persalinan (Jampersal) Dalam Penurunan Angka Kematian Ibu Dan Bayi Di Indonesia. Jurnal Kesehatan Masyarakat, 9(2), pp.197205.

Kamhawia, S., Underwood, C., Murad, H., \& Jabreb, B., 2013. Client-centered Counseling Improves Client Satisfaction with Family Planning Visits: Evidence from Irbid, Jordan. Global Health: Science and Practice, 1(2), pp.180-192.

Lanre, O., 2011. Factors Influencing the Choice of Family Planning Among Couples in Southwest Nigeria. International Journal of Medicine and Medical Sciences, 3(7), pp.227232.

Mehata, S., Paudel, Y.R., Mehta, R., Dariang, M., Poudel, P., \& Barnett, S., 2014. Unmet Need for Family Planning in Nepal during the First 
Two Years Postpartum. BioMed Research International, 2014.

Pasha, O., Goudar, S.S., Patel, A., Garces, A., Esamai, F., Chomba, E., Moore, J.L., Kodkany, B.S., Saleem, S., Derman, R.J., Liechty, E.A., Hibberd, P.L., Hambidge, K., Krebs, N.F., Carlo, W.A., McClure, E.M., KosoThomas, M., Goldenberg, R.L., 2015. Postpartum Contraceptive Use and Unmet Need for Family Planning in Five LowIncome Countries. Reproductive Health, 12(2).

Rizki, N.A., 2012. Perbedaan Pengaruh Metode Focus Group Discussion (FGD) dengan Metode Simulation Game (SIG) terhadap Peningkatan Pengetahuan Siswa Kelas XI tentang Kesehatan Reproduksi Remaja (KRR) di SMK Hidayah Semarang. Jurnal Kesehatan Masyarakat, 8, pp.24-31.

Saka, M.J., Yahaya, L.A., \& Saka, A.O., 2012.
Counseling and Client Provider-Interactions as Related To Family Planning Services in Nigeria. Journal of Education and Practice, 3(5).

Sari, S.K., Suryani, E.S., \& Handayani, R., 2010. Hubungan Konseling Keluarga Berencana (KB) dengan Pengambilan Keputusan Pasangan Usia Subur (PUS) dalam Penggunaan Alat Kontrasepsi. Bidan Prada: Jurnal Ilmiah Kebidanan, 1(1).

SDKI., 2012. Laporan Hasil Survei Demografi dan Kesehatan Indonesia 2012, Jakarta.

Simanjuntak, M., Sarjono, H., \& Zukifli, I., 2014. Pengelolaan Program KB Nasional di DKI Jakarta Tahun 2014. Binus Business Review, 5(1).

Sudarti, K., \& Prasetyaningtyas, P., 2011. Peningkaatan Minat dan Keputusan Beraartisipasi Akseptor KB. Jurnal Dinamika Manajemen, 2(2), pp.130-138. 